\title{
Lumpy Skin Disease
}

\section{Hawsar Yasin Abdulqa1, Heshu Sulaiman Rahman 1,2,3*, Hiewa Othman Dyary ${ }^{1}$ and Hemn Hasan Othman ${ }^{2}$}

${ }^{1}$ Department of Clinic and Internal Medicine, College of Veterinary Medicine, University of Sulaimani, Street 11, Zone 217, Kurdistan Region, Sulaimani New, Northern Iraq

${ }^{2}$ Department of Veterinary Clinical Sciences, Faculty of Veterinary Medicine, University Putra Malaysia, Selangor, Malaysia

${ }^{3}$ Department of Medical Laboratory Sciences, College of Health Sciences, Komar University of Science and Technology, ChaqChaq-Qularasisy, Kurdistan Region, Northern Iraq

"Corresponding author: Heshu Sulaiman Rahman, Department of Veterinary Clinical Sciences, Faculty of Veterinary Medicine, University Putra Malaysia, Selangor, Malaysia, Tel: +964 772615 9598; +964751 146 5757; E-mail: heshusr77@gmail.com

Received date: September 03, 2016; Accepted date: November 10, 2016; Published date: November 14, 2016

Citation: Abdulqa HY, Rahman HS, Dyary HO, Othman HH (2016) Lumpy Skin Disease. Reproductive Immunol Open Acc 1:25. doi: 10.21767/2476-1974.100025

Copyright: (c) 2016 Abdulqa HY, et al. This is an open-access article distributed under the terms of the Creative Commons Attribution License, which permits unrestricted use, distribution, and reproduction in any medium, provided the original author and source are credited.

\section{Abstract}

Lumpy skin disease (LSD) is an infectious, eruptive, occasionally fatal disease of cattle caused by a virus of the family Poxviridae (genus Capripox), which is sometimes also termed as Neethling virus. LSD does not have a high fatality rate, usually less than $10 \%$. LSD has an economical importance because of permanent damage to hides, the prolonged debilitating effect especially in severely affected animals with consequent losses resulting from reduced weight gain, temporary or permanent cessation of milk production as a result of mastitis, temporary or permanent infertility or even sterility in bulls as a consequence of orchitis, and abortion in approximately $10 \%$ of infected pregnant cows.

\section{Keywords: Lumpy skin; Viral infection; Incidence}

\section{Introduction}

Lumpy skin disease (LSD) is an exhausted viral disease that characterised by high economic losses due to chronic debility in affected animals, reduced milk production, poor growth, infertility, abortion, and sometimes death. Moreover, severe and permanent damage can occur to hides, decreasing their commercial value. The more susceptible breeds to LSD infection are related to fine-skinned breeds such as Holstein Friesian (HF) and Jersey breeds [1,2]. In addition, the disease disrupts the trade in cattle and their products from LSD endemic countries [3]. LSD was initially restricted to countries in sub-Saharan Africa, although, there were unconfirmed reports of the disease in cattle in Oman and Kuwait [4,5]. Since 2000, LSD outbreaks have been reported across the Middle East and it is highly likely the disease will become endemic at least in parts of the Region. Incursion of LSD was reported for the first time in Turkey and Iraq in 2013, indicating that the disease has a potential for further spread to the European Union and Caucasus Region, as well as to Asia [6].

Currently, it is widely accepted that LSD is transmitted mechanically by blood-feeding insects such as mosquitoes and stable flies [7]. This is supported by earlier observations that associated most outbreaks with high abundance of biting flies such as in areas along water courses and during wet seasons [8].

\section{History}

The clinical syndrome of LSD was first described in Zambia in 1929. Initially, it was considered to be the result of either poisoning or a hypersensitivity to insect bites. More cases also occur between 1943 and 1945 in Botswana (Bechuanaland), Zimbabwe (Southern Rhodesia) and the Republic of South Africa. A panzootic infection in South Africa affected approximately 8 million cattle till 1949 and consequently incurred enormous economic losses [8-10].

LSD was first found and diagnosed in East Africa (Kenya) in 1957, Sudan in 1972, and in West Africa in 1974. Tanzania, Kenya, Zimbabwe, Somalia and the Cameroon, also reported an outbreaks of epizootic LSD between 1981 and 1986 with mortality rates of $20 \%$ in affected cattle [11]. The disease was restricted to some countries in sub-Saharan Africa between 1929 to 1986 [12].

The LSD also reported in Asian countries such as Kuwait in 1986 [13]. Later on, other countries such as United Arab Emirates, Arab Republic of Yemen, and Democratic People's Republic of Yemen also confirmed or suspected some cases of LSD [14].

Similarly, in the 1989 Israel outbreak of capripox is thought to have been the result of infected Stomoxys calcitrans being carried on the wind from Ismailiya in Egypt [15]. LSD virus infection in cattle was also found in 1992 in Saudi Arabia [16]. Moreover, LSD infection reported in Egypt in 2006, as a result of 
importing infected cattle from the African Horn countries [17] and the disease spreads surprisingly swiftly throughout the whole country in spite of an extensive vaccination program. In the same year, LSD was again reported in Israel, and the Israel authorities speculated that the LSD virus may have already been circulating in other Middle Eastern countries [18]. LSD outbreaks have been reported in the Middle Eastern region since 1990. According to the World Organization from Animal Health (OIE), LSD has been found in Kuwait (1991), Lebanon (1993), Yemen (1995), United Arab Emirates (2000), Bahrain (2003), Israel (2006) and Oman (2010) [19].

\section{Etiology}

Mature capripoxvirions have a more oval profile and larger lateral bodies than orthopoxvirions [20]. Their average size is 320 $x 260 \mathrm{~nm}$ [21].

The LSD virus grows and propagated to a high level in a wide variety of cell cultures such as lamb and calf kidneys, adrenal and thyroid glands, muscle and testes. Sheep embryonic kidneys and lungs, rabbit fetal kidneys and skin, chicken embryo fibroblasts, adult vervet monkey and baby hamster kidneys and primary cell cultures of bovine dermis and equine lungs are also used for that purpose [22].

The development of cytopathic effects may take up to 11 days during primary isolation [23]. There is only one serotype of LSD virus which is very closely related serologically to the virus of sheep and goat pox (SGP), in which it cannot be distinguished easily by routine virus neutralization tests [24].

It has been found that LSD virus strains are essentially identical with each other and with a Kenyan strain (O 240/KS sheep and goat pox virus (SGPV) using restriction endonuclease studies of capripox virus. Other strains of SGPV from Kenya were different from the 0 240/KSGP strain but similar to each other and resemble strains of SGPV from the Arabian Peninsula. The Kenyan group of SGPV strain showed differences when compared with strains from India, Iraq, and Nigeria [25]. The LSD virus is very resistant and well tolerated to most of physical and chemical agents. The virus can remain in necrotic skin for more than 1 month, while remains viable in lesions in air-dried hides for more than 2 weeks at ambient temperature [26].

\section{Epidemiology and Transmission}

Most of LSD virus infections are thought to be transmitted through insects $[8,26,27]$. Pox viruses are highly resistant and can remain viable in infected tissue for more than 120 days or probably longer time. The virus is also found in blood, nasal discharge, lacrimal secretion, semen and saliva, which considered as main sources for LSD transmission [28].

The virus transmission is likely to be mechanical, although there is no enough data demonstrating a particular insect species as a vector of LSD virus transmission. However, the virus has been isolated from Stomoxys, Biomyia fasciata, Tabanidae, Glossina and Culicoides species [28]. The role of all these insects in the transmission of LSD remains to be evaluated in the laboratory and under field conditions [29].
Cross-protection between LSD virus and sheep or goat pox viruses has been exploited by the use of sheep pox virus for the immunization of cattle against LSD in Kenya and in the Middle East. LSD virus is remarkably stable that can be recovered from necrotic skin nodules kept at $-80^{\circ} \mathrm{C}$ for 10 years and from infected tissue culture stored at $4^{\circ} \mathrm{C}$ for 6 months.

Imported Bostaurus breeds such as Friesian cattle with necrotic skin nodules usually show more severe signs of the disease than thick-skinned indigenous breeds such as Afrikaner and Afrikaner cross-breeds. Although, all age-groups are susceptible, but cows in the peak of lactation as well as young animals show more severe clinical disease [30].

\section{Incubation Period}

The incubation period is ranged between 2 to 5 weeks in the field, while after experimental infection by intradermal inoculation, a skin lesion containing virus more probably develops at the injection area within 1-3 weeks [31].

\section{Host susceptibility}

Host susceptibility, dose and route of virus inoculation affect the severity of disease. Both male and female, all age groups and various species and breeds of cattle are considered to be at risk and can get LSD infection, which may followed by severe and serious complications. Among more famous breeds, Bostaurus breeds of cattle are more susceptible for the disease than Bosindicus breeds, although younger animals often affecting and show more severe disease than adult ones [32].

The disease is started with the onset of fever almost 1 week after entering the virus. It has been found that infection with LSD virus is not leading to the characteristics in cattle $[26,33]$.

\section{Pathogenesis}

Intradermal or subcutaneous inoculation of cattle with LSD virus results in the swelling at the site of injection after about 1 week and enlargement of the regional lymph nodes, while generalized eruption of skin nodules usually occurs 7-19 days after injection. Following intradermal inoculation of cattle with LSDV, about $40-50 \%$ of animals will only develop a localized lesion at the site of inoculation or no clinical signs at all, whereas those that have been inoculated intravenously are more inclined to develop generalized lesions and more severe disease [2].

LSD virus in experimentally infected cattle was demonstrated in saliva 11 days after the development of fever, in semen after 22 days, and in skin nodules after 33 days, while the virus not found in urine or faeces. Viremia occurred after the initial febrile reaction and persisted for at least 4 days [34].

Various types of cells such as Pericytes, fibroblasts, epithelial and endothelial cells can be infected by the virus. Viral replication in pericytes, endothelial cells and probably some cells in blood vessel and lymph vessel walls results in severe vasculitis and lymphangitis in affected areas. In severe cases infarction may also result $[35,36]$. 
Viral concentrations at the skin nodules, lymph nodes, liver, kidneys, skeletal muscle, saliva and semen of infected animals however, have not been determined $[37,38]$.

Immunity after recovery from a natural infection is life-long in most survivor cattle; calves from immunized dam acquire maternal antibody and are resistant to clinical disease for about 6 months [35].

\section{Clinical signs and pathological observations}

Skin nodules about $0.5-5 \mathrm{~cm}$ in diameter in whole skin or subcutaneous tissue and swollen superficial lymph nodes especially subscapular and precrural lymph nodes are the main symptoms of LSD infection in most animals [39]. These nodules can also affect the nasal, oral, ocular, and genital mucosa. Their number may range from a few to several hundreds. Cutaneous lesions may resolve rapidly or may indurate and persist as hard lumps, or become sequestrated to leave deep ulcers partly filled with granulation tissue, which often suppurates [40].

Papules most easily seen in hairless areas of perineum, udder, inner ear, muzzle and eyelids [41], which leads to the development of ulcerative lesions with excessive salivation, lacrimation and nasal discharge that may contain LSD virus [42].

Some of the infected cattle may develop oedematous swelling of one or more legs and show lameness. This virus infection is more severe in cows at the peak of lactation and causes a sharp drop in milk production due to high fever $\left(40-41^{\circ} \mathrm{C}\right)$ and secondary bacterial mastitis [39].

If extensive necrosis occurs in the upper respiratory tract, secondary infected necrotic tissue may be inhaled, resulting in pneumonia. Stenosis of the trachea following healing of lesions with scar tissue formation few weeks or even months after infection has been described [43].

\section{Pathological lesions}

Extensive post mortem lesions are appearing of deep nodules in the skin that penetrate into the subcutaneous tissues and adjacent muscles that results in vacuities, necrosis, oedema, congestion with haemorrhage. The mucous membranes of the oral and nasal cavities, pharynx, epiglottis, tongue, nasal cavity, trachea, lungs, testicles and urinary bladder may also contain lesions. Enlargement of the superficial lymph nodes with bronchopneumonia are more pronounced in infected cattle (Figures 1 and 2) [44].

Severe cases of infected cattle with LSD are characterised by edema and areas of focal lobular atelectasis in lungs; pleuritis with enlargement of the mediastinal lymph nodes. Synovitis and tendosynovitis with fibrin in the synovial fluid may also see [45].

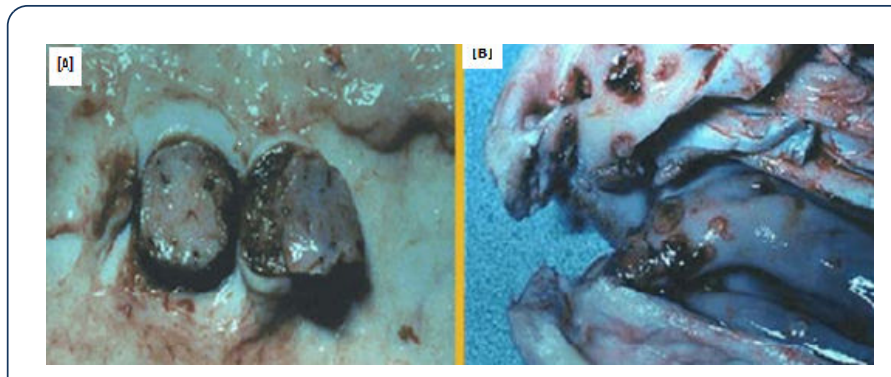

Figure 1: Nodules in lungs $(A)$, Lesions in the $\mathrm{m} / \mathrm{m}$ throughout the GIT (B) (CFSPH, 2011).

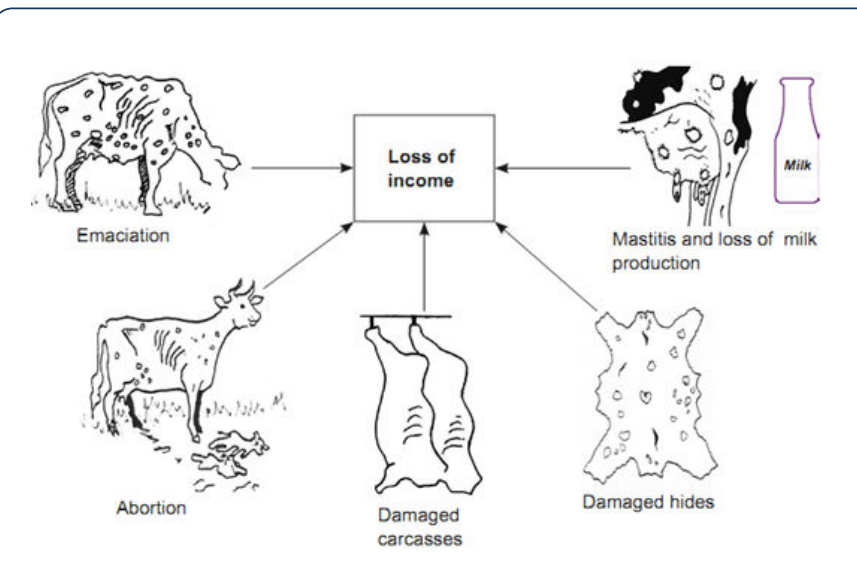

Figure 2: loss in income because of lower production (deaths, milk and meat, abortions, lowered breeding potential, and damage to valuable hides), and the costs of drugs to treat sick animals.

\section{Diagnosis}

At present time, no commercial diagnostic test kits for LSD virus detection are available yet [19]. Thus, the tentative diagnosis of LSD is usually based on the characteristic clinical signs, differential diagnosis, and the clinical diagnosis which is confirmed by laboratory tests using conventional polymerase chain reaction (PCR) techniques [46].

LSD should be suspected clinically when there are characteristic skin nodules, fever and enlargement of superficial lymph nodes [44]. The lumps on the skin follows within 2 days which may appear anywhere on the body from the nose to the tail. Same characteristic lesions appear in the mucosa of the mouth, vagina and conjunctiva. A purulent nasal and ocular discharge are not rare [34].

Laboratory confirmation of LSD virus can be done very rapidly using a PCR method specific for Capri poxviruses or by the demonstration of typical Capri pox virions in biopsy material or desiccated crusts using the transmission electron microscopy (TEM) [12]. Routine diagnostic techniques are described in the OIE Manual of Diagnostic Tests and Vaccines $[44,47,48]$.

Capri poxvirus is distinguished from Para poxvirus, which causes bovine popular stomatitis and pseudo cowpox, but 
cannot be distinguished morphologically from cowpox and vaccine virus infections of bovine [32].

Confirmation of LSD in a new area requires virus isolation and identification [19]. LSD virus can propagate in bovine, caprine or ovine cell cultures; especially lamb testis cells [51]. The cytopathic effect and the intra-cytoplasmic location of inclusion bodies can be used to distinguish LSD virus from the herpes virus, the causative agent of pseudo lumpy skin disease. Recently, direct immunofluorescence, virus neutralization test, enzyme-linked immunosorbent assay (ELISA) and immune blotting (Western blotting) can be used for the identification of LSD virus antigens in infected animals. However, the immunity to LSD infection is predominantly cell mediated, thus the virus neutralization test is not sufficiently sensitive to identify animals with LSD virus due to low level of neutralizing antibody development.

Genome detection using Capri pox virus-specific primers for the attachment protein and fusion protein a gene has been reported, and several conventional and real-time PCR methods have been established to be used on blood, tissue and semen specimens [32].

Cross-reactions occur with bovine papular stomatitis and pseudo cowpox virus when agar gel immune diffusion test is used [44].

Indirect Fluorescent Antibody Test (IFAT) demonstrated to be suitable for use in retrospective serological surveys in a study carried out in Ethiopia, and it was evaluated test for accuracy [49]. The IFAT is a serological test for Capri pox Virus. It was used to detect serum antibody against Capri pox virus and differentiate serological positive and negative animals.

\section{Differential diagnosis}

Misdiagnosis of skin lumps and misreporting of infection have probably been common over the years due to veterinarians not having previous experience of the disease [51].

Although severe LSD is highly characteristic, but milder forms can be confused and misdiagnosed with numerous diseases and infections such as pseudo lumpy skin disease (Bovine Herpes virus), bovine papular stomatitis (Para poxvirus), pseudo cowpox (Para poxvirus), Vaccinia virus and Cowpox virus (Orthopoxviruses) infections, dermatophilosis, insect or tick bites, besnoitiosis, rinderpest, demodicosis, Hypoderma bovis infection, photosensitisation, urticaria, cutaneous tuberculosis and onchocercosis [52].

\section{Economic importance of the disease}

Lumpy skin disease is considered as an economically important disease of cattle; serious economic losses can follow outbreaks that have a high morbidity and can produce a chronic debility in infected cattle [50]. The economic losses due to this disease is due to reduced milk production, in appetite and weight loss, poor growth, abortion, infertility, skin damage and pneumonia especially in animals with I mouth and respiratory tract lesions [32].
Even though, the morbidity and mortality rates of LSD are usually low, it is an economically important disease of cattle in Africa because of the prolonged loss of productivity of dairy and beef cattle, use of the animals for traction, decrease in body weight, mastitis, severe orchitis, which may result in temporary infertility and sometimes permanent sterility. Furthermore, LSD induced economic losses due to reduction of wool and meat qualities [53].

Currently, there is one project in Ethiopia (NAHDIC with integration of $\mathrm{NVI}$ and $\mathrm{MoA}$ ) on improvement of the efficacy of LSD vaccines. Capri pox viruses are classified as potential agents for agro terrorism and listed as notifiable diseases, since they cause serious economic losses [54].

\section{Treatment}

Till this moment, no specific antiviral treatment for LSD infection has been found. Sick animals should be removed from the herd and follow supportive treatment such as antibiotics, anti-inflammatory drugs, and vitamin injections. These therapies are usually the chances for the development of secondary bacterial infections, inflammation and fever, and thus improving the appetite of the animal [55].

Generally, animals infected with LSD will recover as mortality is usually less than $3 \%$. If secondary bacterial infection developed, complete recovery may takes more than 6 months or longer [26].

\section{Control and prevention}

The biting flies and certain tick species are probably the most important method of transmission of the disease, control by quarantine and movement control is generally not very effective. In endemic areas, control is therefore essentially confined to immunoprophylaxis [30].

Two approaches to immunization against LSD have been followed. In South Africa, the Neethling strain of LSD was attenuated by 20 passages on the chorio-allantoic membranes of hens' eggs, but the vaccine virus is now propagated in cell culture [56].

In Kenya, the vaccine produced from sheep or goat pox viruses produces a solid immunity in cattle to LSD. This vaccine has the disadvantage that it can only be used in countries where sheep pox or goat pox is endemic as the vaccine could otherwise provide a source of infection for the susceptible sheep and goat populations.

Susceptible adult cattle should be vaccinated annually to ensure adequate protection against LSD. Approximately $50 \%$ of cattle develop swelling that is $10-20 \mathrm{~mm}$ in diameter at the point of inoculation, and this may be accompanied by a temporary drop in milk yield in dairy cows. The swelling disappear within a few weeks. Calves under 6 months whose dams were either naturally infected or immunized should not be vaccinated in order to preclude interference from maternal antibody. However, calves born from susceptible cows are very susceptible and should be vaccinated to prevent outbreaks [30]. 


\section{References}

1. Davies FG (1991) Lumpy skin disease, a Capripox Virus Infection in Cattle in Africa. FAO, Rome, Italy.

2. Barnard B, Munz E, Dumbell K, Prozesky L (1994) Lumpy skin disease. In: Coetzer J, Thomson G, Tustin R (Edn), Infectious Disease of Livestock. Oxford University Press, Oxford, Capetown, pp: 605-612.

3. Babiuk S, Bowden TR, Parkyn G, Dalman B, Manning L, et al. (2008) Quantification of lumpy skin disease virus following experimental infection in cattle. Transbound Emerg Dis 55: 299-307.

4. House JA, Wilson TM, El Nakashly S, Karim IA, Ismail I, et al. (1990) The isolation of lumpy skin disease virus and bovine herpesvirus-4 from cattle in Egypt. J Vet Diagn Invest 2: 111-115.

5. Kumar SM (2011) An Outbreak of Lumpy Skin Disease in a Holstein Dairy Herd in Oman: A Clinical Report. Asian J Anim Vet Adv 6 : 851-859.

6. Barnard BJH (1981-1987) Onderstepoort Veterinary Institute, South Africa. Personal observation.

7. Carn VM, Kitching RP (1995) An investigation of possible routes of transmission of lumpy skin disease virus (Neethling). Epidemiol Infect 114: 219-226.

8. Von Backstrom U (1945) Ngamiland cattle disease. Preliminary report on a new disease, the etiological agent being probably of an infectious nature. JI SA Vet Med Assn 16: 29-35.

9. Thomas AD, Mare CVE (1945) Knopvelsiekte. J S Afr Vet Med Assoc 16: 36-43.

10. Diesel AM (1949) The Epizootiology of Lumpy Skin Disease in South Africa. In Proceedings of the 14th International Veterinary Congress, London, U.K., pp: 492-500.

11. Brenner J, Haimovitz M, Oron E, Stram Y, Fridgut O, et al. (2006) Lumpy skin disease (LSD) in a large dairy herd in Israel. Refu Vet, 61: 73-77.

12. Davies FG (1981) Lumpy skin disease. In Virus diseases of food animals. E.P. J. Gibbs, edn. New York: Academic Press, pp: 751-764.

13. Ordner G, Lefervre PC (1978) La dermatosenodulairecontagieuse des bovines. Etudes etsytheses de l'Institutd'Elevage et de Medicine Veterinarie Tropicale, Maison-Alfort, Paris, pp. 92.

14. Office International Des Epizooties (1990) World Animal Health 5: 703. 1990

15. Yeruham I, Nir O, Braverman $Y$, Davidson $M$, Grinstein $H$, et al. (1995) Spread of lumpy skin disease in Israel dairy herds. Vet Rec 137: 91-93.

16. Greth A, Gourreau JM, Vassart M, Ba-Uy N, Wyers M, et al. (1992) Capripoxvirus disease in an Arabian Oryx (Oryx leucoryx) from Saudi Arabia. JI WId Dis 28: 295-300.

17. El-Kholy AA, Soliman HMT, Abdelrahman KA (2008) Polymerase chain reaction for rapid diagnosis of a recent lumpy skin disease virus incursion to Egypt. Arab J Biotech 11: 293-302.

18. Brenner J, Bellaiche M, Gross E, Elad D, Oved Z, et al. (2009) Appearance of skin lesions in cattle populations vaccinated against lumpy skin disease. Vaccine 27: 1500-1503.

19. Tuppurainen ESM, Oura CAL (2012) Review: Lumpy Skin Disease: An Emerging Threat to Europe, the Middle East and Asia. Transbound Emerg Dis, 59: 40-48.
20. Munz EK, Owen NC (1966) Electron microscopic studies on lumpy skin disease virus type 'Neethling'. Onderstepoort J Vet Res 33: 3-8.

21. Ghaboussi B (1978) Morphological and physical characteristics of sheep and goat pox viruses. Archiv Institut Razi 30: 107-115.

22. Alexander RA, Plowright W, Haig DA (1957) Cytopathogenic agents associated with lumpy skin disease of cattle. Bull Epizoot Dis Afr 5: 489-492.

23. Weiss KE, Geyer SM (1959) The effect of lactalbuminhydrolysate on the cytopathogenesis of lumpy skin disease virus in tissue culture. Bull Epizoot Dis Afr 7: 243.

24. Burdin ML (1959) The use of histopathological examinations of skin material for the diagnosis of lumpy skin disease in Kenya. Bull Epizoot Dis Afr 7: 27-36.

25. Kitching RP, Bhat PP, Black DN (1989) The characterization of African strains of capripoxviruses. Epidemiol Infect, 102: 335-34.3.

26. Weiss KE (1968) Lumpy skin disease. In Virology Monographs, 3, New York: Springer Verlag, pp: 111-131

27. MacOwan KDS (1959) Observations on the epizootiology of lumpy skin disease during the first year of its occurrence in Kenya. Bull Epizoot Dis Afr 7: 7-20.

28. http://www.fao.org/docrep/u4900t/u4900t0d.htm

29. Kitching RP, Mellor PS (1986) Insect transmission of capripoxviruses. Res Vet Sci 40: 255-258.

30. Coetzer JAW, Tuppurainen E (2004) Lumpy skin disease, in: Infectious diseases of livestock, edited by Coetzer JAW, Tustin RC. Cape Town: Oxford University Press Southern Africa, 2: 1268-1276.

31. Haig DA (1957) Lumpy skin disease. Bull Epizoot Dis Afr 5: 421-430.

32. OIE (2010) Terrestrial Manual of Lumpy Skin Disease, Chapter 2.4.14. Version adopted by the World Assembly of Delegates of the OIE in May 2010, OIE, Paris.

33. Onderstepoort J (2005) Vet Res 72: 153-164.

34. Weiss WE (1968) Lumpy Skin disease. In Emerging Diseases of Animals. FAO Agricultural Studies Bulletin, 61, 179-201.

35. Prozeesky L, Barnard BJH (1981) A study of the pathology of lumpy skin disease in cattle. Onderstepoort J Vet Res 49: 167-175.

36. Capstick PB (1959) Lumpy skin disease: Experimental infection. Bull Epizoot Dis Afr 7: 51- 62.

37. Thomas AD, Robinson EM, Alexander RA (1945) Lumpy skin disease-knopvelsiekte. Onderstepoort J Vet Res, Veterinary Newsletter, pp: 10.

38. Tuppurainen ESM (2005) The detection of lumpy skin disease virus in samples of experimentally infected cattle using different diagnostic techniques. Onderstepoort J Vet Res 72: 153-64.

39. http://c.ymcdn.com/sites/www.eazwv.org/resource/resmgr/ Files/Transmissible_Diseases_Handbook/Fact_Sheets/ 039_Lumpy_Skin_Disease.pdf

40. Wainwright Sh, El Idrissi A, Mattioli R, Tibbo $M$, Njeumi $F$, et al. (2013) Emergence of lumpy skin disease in the Eastern Mediterranean Basin countries. Emp Watch 29: 2.

41. Babiuk S, Bowden TR, Boyle DB, Wall ace DB, Kitching RP (2008) Capripoxvi ruses: An Emerging Worldwide Threat to Sheep, goats and Cattle. Transbound Emerg Dis 55: 263-572. 
42. DE Boom HPA (1948) Knopvelsiekte. South African Scientific Bulletin 1: 44-46.

43. CFSPH (2008) The Central for Food Security and Public Health, lowa State University, College of Veterinary Medicine.

44. http://web.oie.int/eng/maladies/Technical\%20disease\%20cards/ LUMPY\%20SKIN\%20DISEASE_FINAL.pdf

45. Tuppurainen SM (2005) The detection of lumpy skin disease virus in samples of experimentally infected cattle using different diagnostic techniques, Onderstepoort J Vet Res, 72: 153-164.

46. OIE (2011) Lumpy Skin Disease. Terrestrial Animal Ethiopian Veterinary Association (EVA). Addis Health Code. OIE, Paris.

47. El-Kenawy AA, El-Tholoth MS (2011) LSD Virus Identification in Different Tissues of Naturally Infected Cattle and Chorioallantoic Membrane of Embryonated Chicken Eggs Using Immune fluorescence Immunovperoxidase Techniques and Polymerase Chain Reaction. Int J Virol 7: 158-166.

48. Gari GF, Biteau-Coroller C, LeGoff P, Roger CF (2008) Evaluation of Indirect Fluorescent Antibody Test (IFAT) for the Diagnosis and Screening of Lumpy Skin Disease Using Bayesian Method. Vet Microbiol 129: 269-280.

49. Woods JA (1988) Lumpy skin disease: A review. Trop Anim Health Prod. 20: 11-17.
50. Siraw B (1987) Bovine Dermatophilus Infection in Mend You Province: Prevalence and Relative Efficacy of Different Drugs against the Disease. Onderstepoort j vet res 83: 1 .

51. Yacob HB, NesanetandDinka A (2008) Part II:Prevalence of major skin diseases in cattle, sheep andgoats at Adama Veterinary Clinic, Oromia regionalstate, Ethiopia. Rev Med Vet 159: 455-461.

52. Davies FG (1991) Lumpy skin disease of cattle: a growing problem in Africa and the Near East. World Animal Review 68: 37-42.

53. Davies FG (1982) Observations on the epidemiology of lumpy skin disease in Kenya. J Hyg 88: 95-102.

54. Van Rooyen P, Munz KE, Weiss KE (1969) The Optimal Conditions for the multiplication of Neethling-type lumpy skin disease virus in embryonated eggs. Onderstepoort J Vet Res 36: 165-174.

55. Capstick PB, Prydie J, Coackley W, Burdin ML (1959) Protection Of cattle against 'Neethling' type virus of lumpy skin disease. Vet Rec 71: 422.

56. Nawthe DR, Asagba MO, Abegunde A, Ajayi SA, Durkwa L (1982) Some observations on the occurrence of lumpy skin disease in Nigeria. Zentralbl Veterinarmed B 29: 31-36. 